\title{
SLUM TOURISM: STATE OF THE ART
}

\author{
FABIAN FRENZEL, ${ }^{\dagger} \dagger$ KO KOENS, † MALTE STEINBRINK, $†$ AND CHRISTIAN M. ROGERSON† \\ *School of Management, University of Leicester, UK \\ †School of Tourism \& Hospitality, University of Johannesburg, South Africa \\ $\ddagger$ Academy of Hotel and Facility Management, NHTV Breda University of Applied Sciences, \\ The Netherlands \\ §Institute for Migration Research and Intercultural Studies, University of Osnabrück, Germany
}

\begin{abstract}
This article provides a view on the state-of-the-art literature on slum tourism. It points to the rapid growth of slum tourism research in recent years and highlights the main avenues that research has thus far explored in areas such as slum tourism history, slum tourist subjectivity, resident perspectives, slum tourism operations, economics, and mobilities. With the advent of slum tourism the relationship of poverty and tourism has changed. Tourism is no longer only a means to fight poverty, but poverty is an attraction of tourism. This has consequences for the relationship of slum tourism to other forms of tourism where poverty functions as an attraction, like volunteer or developmental tourism. The article identifies research gaps as well as avenues for further research.
\end{abstract}

Key words: Slum tourism; State of the art; Poverty alleviation; Mobilities; Development

Introduction

Research on slum tourism has evolved significantly in the last few years and this is reflected in the appearance of an ever-growing number of studies, the publication of edited collections and special issues, as well as the formation of a research network that has held two international conferences in the last 4 years. The growing research area is distinctly interdisciplinary, much like tourism studies in general. One reason for the expansion is, quite simply, the overall growth of slum tourism as a real-world activity. As the number of locations has increased in the past 20 years, so has the number of tourists taking part in slum tourism. Recent estimates by the authors point to an annual number of over 1 million slum tourists. Most of these tourists will go on 2-3-hour-long guided tours in slums and $80 \%$ will do so in just two destinations: the townships of South Africa and the favelas of Brazil (Fig. 1). Within these destinations South Africa has township tours across nearly all the country's largest cities and towns, while favela tourism in Brazil is mainly concentrated in Rio de Janeiro.

Slum tourism is thus a mass tourism phenomenon occurring only in few destinations and a niche 

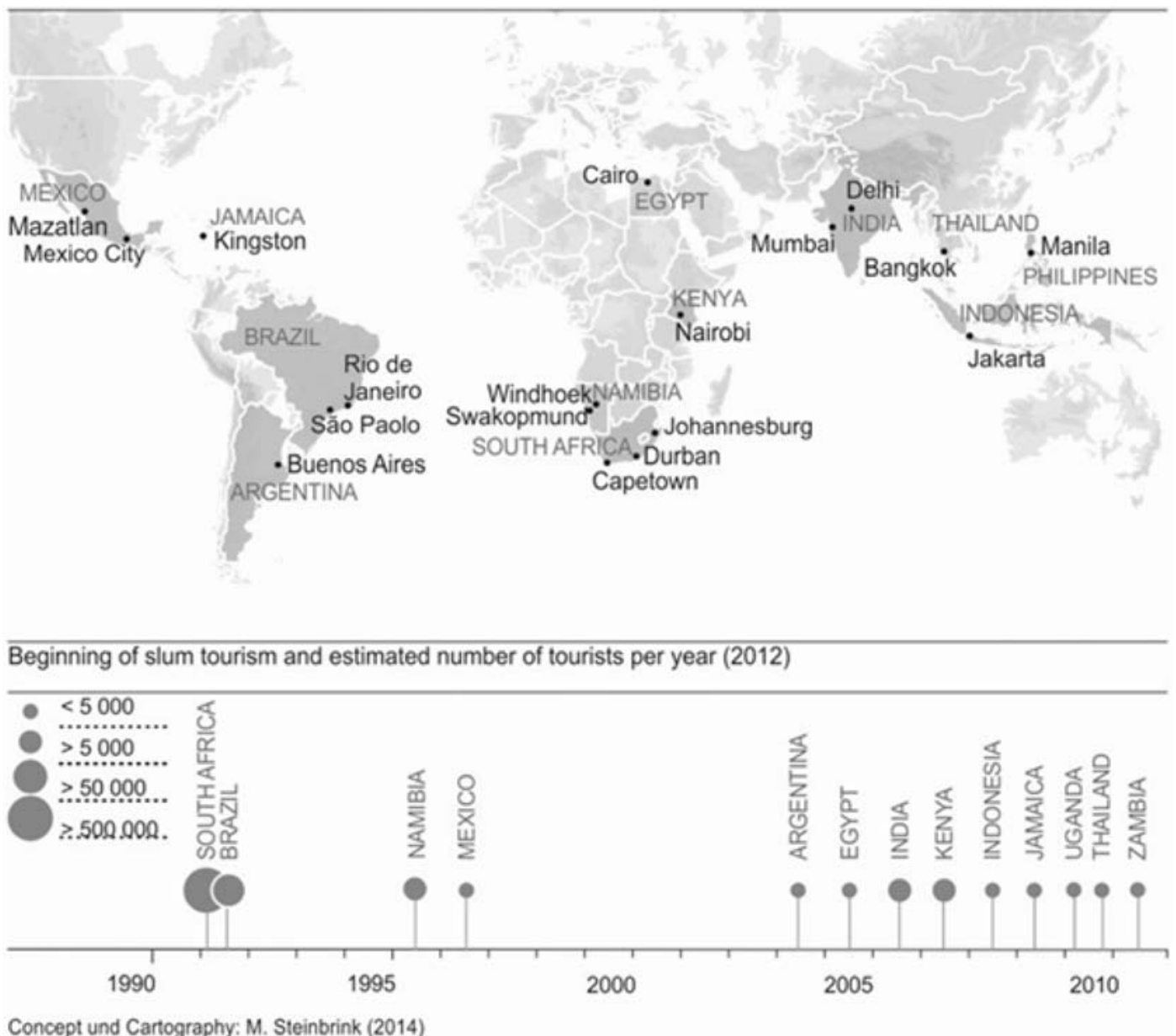

Figure 1. Expansion of slum tourism.

form of tourism in a growing number of other destinations. The growth of destinations as well as the spreading of the phenomenon is a fascinating area of research. The routes of the traveling concept of slum tourism are still to be explored. The connections that exist between operators have been discussed only to a limited extent in the literature (Dyson, 2012; Freire-Medeiros, 2013; Meschkank, 2011; Steinbrink, Frenzel, \& Koens, 2012). Such work has shown that one of the founders of slum tourism operations in Mumbai's Dharavi slum had been inspired by tours in which he took part in Rio de Janeiro. More recently he has acted as consultant to the development of a slum tourism operator in Manila. Also, one of the first operators of favela tourism was inspired when he had visited
Senegal and took part in a tour of a poor neighborhood there. And a volunteer tourist from the Netherlands, who had participated in a township tour in Cape Town has developed the concept of the first slum tour in Kampala, Uganda as part of his job for an NGO. There are many more of these individual connections. One of the key operators in favela tourism in the favela "Complexo Alemao" had worked in coastal tourism in Bahia, before sensing the opportunity of favela tourism development after the cable car was built in Alemao (see LeBaron in this issue). Tourism operators in slum tourism destinations in southern Africa tend to take inspiration from South African township tourism. The concept of slum tourism is now floating freely as an option for tourism development across 
countries. Within South Africa even in small towns and cities township tours of one sort or another are organized. This "viral" spread of slum tourism is not restricted to the Global South, as homeless tours have developed across destinations in Northern Europe, adapted and changed to fit different destinations (Burgold, 2014).

A key role in this expansion is played by policy. In the most frequently visited destinations-South Africa and Rio de Janeiro-policy has promoted and supported the expansion of slum tourism for social and developmental ends and to aid the improvement of security. South African tourism policy and planning for townships started in the early postapartheid years. Key locations of the antiapartheid struggle, like the area of Vilakazi Street in Soweto, saw the creation of museums and the development of different sites of political heritage. Township tourism development has been quickly seized upon as an opportunity of the white-owned mainstream tourism industry, and policy has attempted to counter this trend to ensure benefits from this tourism are actually felt in the community. In the run up of the 2010 FIFA World Cup, large-scale investment went into the creation and organization of new township tourism offerings like Bed and Breakfasts and new heritage routes (Naidoo, 2010).

In Rio de Janeiro favela tourism has been part of urban tourism planning for over a decade with plans for museums of the favela in Providencia (Menezes, 2012). With the Rio Top tour, inaugurated as part and parcel of the pacification of the favela Santa Marta, tourism development has also been supported in the training of guides and the creation of promotional material and web pages where different tourism offerings are integrated. The most ambitious tourism-related policy instrument, perhaps, has been the construction of the aforementioned cable car to the favela Complexo Alemao. This cable car has increased tourist numbers in the complexo, from zero to several thousand in just a couple of years. The cable car was never meant to be a tourism attraction only, but tourism was part of the strategy to make the investment viable. Rio de Janeiro followed the example of Medellin in Colombia (Hernandez-Garcia, 2013). In the meantime, two more cable cars are in construction in Rocihna and Providencia favelas. As in South Africa, much enthusiasm of policy involvement in
Rio de Janeiro results from upcoming mega-events (Steinbrink, 2014).

The expansion of slum tourism and slum tourism research also has to do with the nature of research. Previous reviews of the literature pointed to the overlaps that exist with other forms of tourism (Frenzel \& Koens, 2012; Steinbrink et al., 2012). Accordingly, certain practices can be described both as volunteer tourism or slum tourism, while they could also be labeled as dark tourism or as developmental tourism. The tendency of tourism academics to create niches notwithstanding, different empirical trends seem to converge over the relationship of poverty and tourism. This relationship is no longer restricted to the effects tourism may have on poverty, but equally concerns the reflection of poverty as an attraction, a theme of tourism (Frenzel, 2013).

In this article we chart the state of the art of slum tourism research. First we address the research on slum tourism's history. The relationships between contemporary forms of slum tourism and historical slumming are multiple and much can be learned from the long-lasting legacy of slum tourism as a social practice. Following this historical discussion, we reflect research on the slum tourist, taking in the motivations and gazes that drive contemporary slum tourists. Slum tourists experience needs to be produced and the increasingly professionally operating slum tour operators and the principles of their operations are still not broadly studied, as our review shows. Pertinent to slum tourism operations are the overall economics of the pursuit. This extends to slum tourism's moral justification with regards to the question of who benefits from its development. While there is little evidence for significant effects in purely monetary terms, some attention has been placed on attempting to model the symbolic valorization and its effects in slum tourism. This includes the view of slum tourists as cocreators of the destination as well as the observable role of slum tourism in some destinations in gentrification processes. An area long overlooked in the study of slum tourism is resident perceptions, although more research is starting to emerge. In the last section we discuss new perspectives on slum tourism, derived from a reflection on the mobilities of slum residents. The article is concluded with recommendations for further research. 


\section{Historical Slumming}

While slum tourism in the Global South has only relatively recently developed, the tourist gaze on urban poverty and slums is long-established in the Global North. The following quote of Nicolas Wiseman (1850), Archbishop of Westminster in that time, describes the living conditions in a section of Victorian London called "Devils’ Acre”:

\begin{abstract}
Close under the Abbey of Westminster there lie concealed labyrinths of lanes and courts, and alleys and slums, nests of ignorance, vice, depravity, and crime, as well as of squalor, wretchedness, and disease; whose atmosphere is typhus, whose ventilation is cholera; in which swarms of huge and almost countless population, nominally at least, Catholic; haunts of filth, which no sewage committee can reach-dark corners, which no lighting board can brighten. (p. 30)
\end{abstract}

This passage was widely quoted in British newspapers, and finally led to the popularization of the term "slum" to describe bad housing. It is considered to be the oldest historical source proving the occurrence of the term "slum" in Standard English. When looking at the semantic field that unfolds within this passage it almost seems that the dominant ascriptions have hardly changed over the last 160 years (Fig. 2).

The "slum" then symbolizes the "dark," the "low," the "unknown" side of the city; slums are "places of the unknown Other." They are a cause for concern and fear ranging from sanitary and hygienic conditions to more profound worries about the decline of civilization and the loss of public control. The imagined geography of "the slum" is that of another world-chaotic, uncivilized, and horrifying. At the same time this threatening strange "urban terra incognita" where the other half lives also promises adventures, enticing bourgeois curiosity. The curiosity about the "slum" is at least as old as the slum itself. During the time when "slum" evolved in Standard English, the word "slumming" also found its way into London's "West-SideLingo." The term described the burgeoning leisure time activity of upper class Londoners who were setting off for the "undiscovered land of the poor" in the East End in the middle of the century. The curiosity evoked suspicion from the very beginning, particularly in regard to the motivation of the so-called slummers. Slumming, the word and the activity associated with it, was distinguished historically by a persistent pattern of disavowal.” (Koven, 2004, p. 8).

This early slumming has been regarded as forerunner of today's slum tourism (Dowling, 2009; Koven, 2004; Steinbrink, 2012). Slumming expanded just before the turn of the 20th century to New York. Wealthy Londoner tourists had imported the idea, eager to visit the poorer areas in New York (e.g., Bowery) in order to compare them with "their"

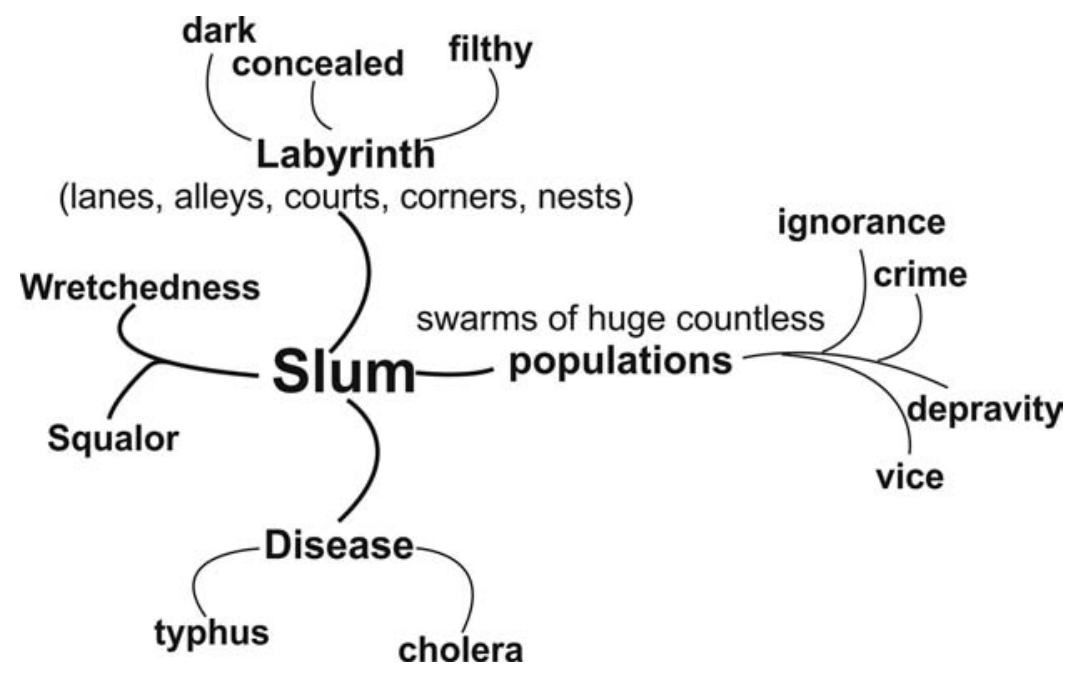

Figure 2. Semantic field of Wiseman’s “slum” (cf. Frenzel \& Steinbrink, 2014). 
slums at home. Tourist guidebooks suggested routes for walking tours through various impoverished areas. Additionally, the first commercial tour companies specializing in guided slum visits were established in Manhattan, Chicago, and San Francisco. In the early 20th century, "slum tourism" in a more narrow sense emerged for the first time, and slumming became an integral part of urban tourism. The historic cases of slumming in the Global North are well documented. For the Victorian era of slumming the works of Koven (2004), Ross (2007), Seaton (2012), and Steinbrink (2012) are worthwhile readings. The studies of Conforti (1996), Sandfort (1987), Cocks (2001), Koven (2004), Heap (2009), and Dowling (2009) all address different aspects of early slumming in the US.

The reading of these contributions on early forms of slum tourism in the Global North and the comparison with research on the recent phenomenon of slum tourism in the Global South point to certain continuities and similarities: this slum is seen in tourism and literature as the "place of the 'Other' " of the visitors' experience. The nature of this Other is not just reflecting poverty, and the slum was more than just the "place of poverty." The slum was also a surface for the projection of a "societal "Other'" loaded with repulsion and fascination. The studies dealing with the different times and contexts of slumming indicate that dominant modes of social distinction are negotiated through the topography of urban landscapes. It remains a central area of inquiry for slum tourism research to relate historical slumming to contemporary forms. The continuities and differences appear in several domains, one of which is the study of the slum tourist and his/ her experience.

\section{Slum Tourists}

A key issue for contemporary slum tourism research is slum tourists. Thus far research has investigated tourists' desire to go to the slums mostly through broad surveys and qualitative interview approaches. Rolfes, Steinbrink, and Uhl (2009) found tourists of townships to be curious, either because they sought the thrills of the unknown or because they were wanting to contribute to the development of the country, to learn and to see the "real picture." Similar results have been observed across other destinations. In Mumbai and Delhi curiosity and the desire to see more of the real India was often stated by tourists as their main reason to enter the slum (Basu, 2012; Dyson, 2012; Meschkank, 2011). In Rio de Janeiro, survey results pointed to similar results (Freire-Medeiros, 2013).

To date there has been no research on slum tourist types, but it would be interesting to reflect on the differences between pioneering slum tourists and early adopters on the one hand and tourists that only go to more mature destinations on the other hand. Steinbrink et al. (2012) have argued that every destination has "professional slummers," people who enter the slum for a variety of professional reasons like research, journalism, and art as well as social and developmental work, activism, religion, and urban planning. These professional slummers often play a key role in establishing infrastructures that may then be exploited by more conventional tourists. This includes the setting up of tour guide operations, hospitality, and other services to enable access. Once slum tourism has grown to a certain size in one destination, slum tourism operates automatically in the sense that a visit is now a "must-do" on the list of all tourists. Moreover motivations are hard to grasp, and it might be more useful to stick to the question of broader discursive frames employed to justify visits to slums. Tour operators, often more readily than tourists, employ these frames and give tourists the justifications they will later share as part of their telling of the experience.

Broadly speaking, slum tourist motivation seems to follow structural patterns that are similar to overall tourism. A key frame is the attempt to see "reality," a promise of authenticity that runs through many forms of tourism (MacCannell, 1976) and is highly prevalent in slum tourism (Dyson, 2012; Meschkank, 2011). It is also possible to identify the construction of particular gazes (Urry, 2002). In the early phases of slum tourism this is often a romantic gaze in which the slums are cast as having community and locality, constructed as absent from the formal neighborhoods of the city. As indicated earlier, this romantic gaze can be identified in historical perspective and often includes an element of fear and desire that cast the Other to define the self.

Close to this romantic gaze is the more interventionist charitable gaze reflected, for example, 
in tourists seeking to help and support slum dwellers. Most tour operators will provide narrative and experiential frames that enable tourists to think of themselves as agents of change in the slums. Desire to help and support the slum in direct interventions is a central motivator for many tourists. It is also a key field of overlap between slum tourism and other forms of active tourism like those of volunteers, activists, and developmental tourists. The massive expansion of these new forms of interventionist travel has been interpreted in different ways (Butcher, 2003, Wearing, 2001). Some have pointed to the increasing overlaps of leisure and work whereby tourism has to be made productive for the accumulation of social skills and professional experience (Binder, 2004); others have focused on the psychological and social consequences of these practices (Crossley, 2012; Rogerson \& Slater, 2014; also see Raes in this issue). Amid constant growth in the last few years volunteer tourism has diversified (McGehee, 2014). In Nairobi and Johannesburg we see the development of commercial short-term (1-5 days) volunteering opportunities in slums, a clear sign of the merging of volunteering and slum tourism trends in some destinations.

Slum tourists' desires also converge around the more tangible experiences: the smells, sounds, mazelike streets, and atmospheres of slums (Diekmann \& Hannam, 2012). This is particularly important because the slum tourism experience here relates to forms of slumming that take place fully mediated, in literature, movies, and video games. Literacy slumming (Seaton, 2012; Williams, 2008) is probably older than literal slumming, but both are closely connected as research by Seaton (2012), Linke (2012), and Frisch (2012), among others, has shown. Destinations generally receive higher visitor numbers once films and books have brought them to the attention of a global audience. Slum imaginaries are central to the symbolic valuation of slum neighborhoods in tourism, in the way they often project cool imaginaries that may operate as eye openers to further slum tourism (Freire-Medeiros, 2013; Mendes, 2010). Here we may also refer to the role of artists, activists, academics, and journalists in creating "cool” slum destination images as well as serving as actual guides into the slum (Steinbrink et al., 2012). Some have argued that the actual experience of slums might enable the subject to escape from iron cages of representation and gazes (King \& Dovey, 2012) while others have pointed out how little the corporal experience of poverty and the slum does to change dominant discourses in which the experience is framed (Crossley, 2012). Further research is needed to reflect on the relationships between slum imaginaries and slum tourism.

\section{Slum Tourism Operations}

Slum tourism is increasingly professionally produced in slum tourism operations. While in its initial stages, slum tourism often involves little more than a small group of local tour operators and guides; in more mature destinations a wide range of smaller and larger businesses with varying degrees of professionalism are involved in tour operation, guiding, crafts, performance, visitor attraction, accommodation, and catering (e.g., restaurants or bars) (FreireMedeiros, 2013; Koens, 2014).

The majority of slum tours across the world are done on foot or by jeep, motorcycle taxi, or minibus. Motorized tours commonly include some sort of walking tour or visit that takes tourists into the slum, meaning that the much-criticized drivethrough coach tours have become rare (Frenzel, 2014a). Even though tours are placed in a context of a cultural experience, using a narrative of progress, the main subjects continue to be the exoticism of poverty and the poor living conditions of residents (Freire-Medeiros, 2010; Rolfes, 2010; Steinbrink, 2012). Some diversification can be observed in mature destinations. In the favelas, tours to favela parties or focusing on Brazilian funk music are now offered (Rolfes, 2010), while in South Africa music tours and bicycle trips to the townships provide novel ways of experiencing the townships. In both countries the FIFA World Cup football has resulted in a number of tours that take football or another sports experience as center of a tour. One recent development in Soweto, South Africa is the offering of paintball and bungee jumping (McKay, 2013).

Tour guides, most of whom are male and relatively young, act as an intermediary between the tourists and the visited community. They both work for tour operators as well as operate independently, organizing tours themselves and competing with 
tour operators. Compared to other business types they are in high demand, and relatively well paid, while they also gain status from working with tourists (Furtado, 2012; Harvey, 2011). Performance artists and craft workers, on the other hand, earn less from tourism and mostly scrape by with their limited income or combine tourism and other work. Nearly all tours take in township attractions like nurseries, day-care centers, and churches, as well as local enterprises. Remuneration for visitor attractions is scant and largely these actors depend on donations from the tour operators or guides (Dyson, 2012; Koens \& Thomas, 2015).

Staying overnight in the slums remains a niche market and is mainly practiced in the townships in South Africa and Namibia and favelas in Rio, although exceptions in other parts of the world can be found (e.g., Jakarta, Indonesia) (Weidemann, 2014). Providing accommodation has been described as the prototype of "consensual poverty tourism," even when from a financial perspective accommodation brings little income (Whyte, Selinger, \& Outterson, 2011, p. 344). The majority of accommodation businesses operate as small-scale homestays or B\&Bs with the exception of a small group of larger, more commercial, businesses that often target backpackers. Catering businesses are a highly diverse group. They consist of "authentic restaurants" where tour groups can sit down and eat, and street food restaurants, but also bars and dancehalls. What sets accommodation and restaurants apart from other slum tourism businesses is that they are often family businesses and female led (Duarte, 2010; Koens, 2014; Rogerson, 2004a).

It would be negligent to ignore offerings by NGOs or other not-for-profit institutions when discussing the supply side of slum tourism, as these provide opportunities for both leisure and professional slummers. Commonly NGOs offer tourists the opportunity to participate in a tour that displays their work or allows them to stay on site and volunteer as teachers or community development workers. While such work may have the potential to empower local residents more than commercial tourism (Aquino, 2013), the efforts of NGOs are certainly not without issues. A good example of this comes from Dürr (2012a, 2012b), who describes a tour to the garbage dump in the city of Mazatlán,
Mexico by an evangelical church run by American expats. Dürr observed how these tourists developed slum tourism in Mexico as a way to fill their leisure time with meaningful engagement as well as tackling what they saw as social problems in the country they lived. In her discussion she poignantly highlights the political/evangelical aspects of such work, as visited residents are urged to join the church to ensure they will continue to receive economic benefits. Additionally, the progressively more commercial outlook of NGOs increasingly blurs the line between theirs and social enterprises or other forms of "socially responsible" commercial offerings (Becklake, 2014), while the deeper immersion of tourists with limited understanding of the local context can be problematic too (see, e.g., Crossley, 2012; also see Raes in this issue).

Turning towards the supply chain of slum tourism, the dominance of actors from outside of the slums becomes clear, particularly in the case of organized tours. In practically all major slum tourism destinations the most popular tours are run by tour operators, NGOs, or guides who are based outside the slums (Duarte, 2010; Dyson, 2012; Kieti \& Magio, 2013; Koens, 2014). Due to associations of danger, it is still uncommon for tourists to visit slums as independent travelers. Most tours are commonly booked beforehand through a limited set of brokers at tourism offices or travel agencies. Within the slums dependency relations also can be observed. In most slums it is tour operators who maintain strict control over the itinerary of the tours (Chege \& Mwisukha, 2013; Dyson, 2012; Harvey, 2011; Mekawy, 2012). In contrast, favela tours are regularly visited by taxi drivers and private guides too, who then take control of what is visited (Freire-Medeiros, 2009). Since slum tourism is often structured in such a hierarchical way, actors are dependent on others higher up in the hierarchy for custom, leading to frictions and alleged power abuse. The importance of issues of power among slum tourism businesses has received only little attention in the wider ethical debates surrounding slum tourism, but at least in South Africa and Brazil it is one of the main issues on the supply side and requires further investigation (Frisch, 2012; Harvey, 2011; Koens, 2012; Koens \& Thomas, 2015). Of particular concern are ways to negotiate and manage such structures in a highly 
uncertain local context. This can be related to the economics of slum tourism and its potential for providing financial incentives to local communities.

\section{The Economics of Slum Tourism}

The valorization and marketing of slums, township, or favelas as tourism attractions has attracted much controversy, most notably as "voyeurism and exploitation for commercial ends" (Burgold \& Rolfes, 2013, p. 162; see also George \& Booyens, 2014; Steinbrink, Buning, Legant, Süßenguth, \& Schauwinhold, 2015). For advocates of slum tourism the economic benefits of funneling tourist dollars into slums are one its central advantages (Frenzel, 2013). Organizationally, the business of slum tourism straddles the divides between formal and informal economies with guided tours increasingly professionalized but with the existence of a parallel "large number of informal businesses" (Rolfes et al., 2009, p. 11). However, often, as in the case of South Africa, there occurs the phenomenon of "displacement" with some of the earliest tours operated by local residents and subsequently displaced by the more professional services offered by larger tour and travel companies, many of them in external (white) ownership (Rolfes et al., 2009). Indeed, in South Africa, while some tour companies are locally based in slum tourism destinations, most large tour operators are white owned and based externally in Johannesburg, Pretoria, or Cape Town (Booyens, 2010; George \& Booyens, 2014; Nemasetoni \& Rogerson, 2005; Rogerson, 2008a, 2008b). This structure and geography of control of the economy of slum tourism is critical to understand the patterns of leakages and limited local benefits that are well documented. Among others, Freire-Medeiros (2009), drawing evidence from the favelas, points to the high levels of economic leakage occurring in slum tourism and recommends that visitors be made aware of what (small) portions of the profits of slum tours actually goes back into local communities.

One of the nonnegotiable principles of sustainability for any tourism project, according to Mowforth and Munt (2009), is channeling of benefits to local communities. In many cases, however, slum tourism fails to meet this baseline for sustainability. At the outset the limited nature of markets for the "niche” of slum tourism must be clearly recognized as one critical causal factor of constrained local impacts. For example, whereas the iconic township tours of Soweto and certain Cape Town townships attract substantial numbers of international tourists, the serial reproduction of township tours into other less well-known South African townships (such as Muncieville, Tembisa, or Katorus) has failed to lure more than a handful of visitors. The widespread geographical diffusion and increasingly "saturated" markets for the products of poverty tours contributes to the faltering of township tourism with only a few localities now managing to sustain any serious interest in it. In part this situation is a consequence of optimistic entrepreneurs seeking to replicate the seeming success stories of others in Soweto and Khayelitsha but it is exacerbated by the activities of South African local governments which, as part of their developmental mandate for energizing projects for local economic development in poorer communities, pinned their hopes on the niche of slum tourism as economic savior. In Johannesburg's Alexandra township adjacent to Sandton, which offers the largest national cluster of upmarket hotels accommodating international tourists, Allie-Nieftagodien (2013) highlights the disappointing numbers of visitors as a key explanation for the lack of pro-poor tourism impacts and of the associated failure of craft projects set up to target the market of slum tourists. The outcome has been the dissolution of noble projects that have not afforded any long-term sustainable solution to the unemployed or of a pro-poor tourism approach in search of net benefits that end up in the pockets of the poor. Fragmentation and poor organization of support structures also contribute to limited pro-poor impacts. In a critical assessment of efforts to promote pro-poor tourism in Alexandra it is concluded:

\footnotetext{
The picture that emerges is of lack of commitment to the ideals of pro-poor tourism. Instead, those who became the key role players in the sector seemed more interested in heading organisations that would have access to resources rather than facilitating and supporting the involvement of poor people in the local tourism industry. (AllieNieftagodien, 2013, p. 70)
}

The evidence surrounding the local economic impacts of slum tourism is no less promising elsewhere in Africa. Kieti and Magio (2013) show 
the local economy of Kibera "has not changed as a result of slum tourism"; indeed, as a whole, it "has very little to do with slum tourism" and "only a few projects like toilet projects and water projects can be attributed to slum tourism” (p. 51). Residents of Kibera slum in Nairobi emphasize the "real" beneficiaries of slum tourism once again are nonresidents (Kieti \& Magio, 2013). Here one of the core barriers to economic trickle down is "the lack of interaction between the slum dwellers and slum tourists" which is frequently the consequence of tour operators limiting interactions between tourists and slum dwellers potentially to "reduce the embarrassing behaviour of soliciting for handouts” (p. 49) or elsewhere "to keep tourists away from irritating or shocking experiences” (Rolfes, 2010, p. 430). It has been argued that Kibera residents "did not generate adequate benefits from the development of slum tourism" (Chege \& Waweru, 2014, p. 43) and instead the prime beneficiaries were the tour operating enterprises, some of which were foreign rather than domestically owned and many of which had Wazungus (whites) as directors. In terms of the direct benefits to the community from wage employment it was disclosed few residents were employed in slum tourism-related activities. Involvement mostly concerned provision of accommodation in the form of small numbers of homestays or other services such as drivers, guides or most notably as security guards (Chege \& Waweru, 2014). Essential blockages to greater propoor local impacts relate to the limited capacity of slum residents to engage in slum tourism activities and in particular the absence of capacity to establish small enterprises (see Chege \& Mwisukha, 2013; Chege \& Waweru, 2014). Related to this is work from Koens (2014), who investigated the orientations of small township tourism business owners and found only a quarter of them actively seek business growth, while others prefer to use their work in tourism to diversify income streams, for lack of other options or because of lifestyle reasons. This diversity of orientations is poorly recognized among government and other tourism actors and sheds some light on the difficulties of residents to establish economically growing and thriving enterprises.

From South African research further critical issues relate to the observed lack of diversity of product offerings by local entrepreneurs, which results in an oversupply of certain products (such as restaurants and bed and breakfasts), poor product quality, and lack of any effective cooperation to compete collectively by local businesses (Koens, 2012; Koens \& Thomas, 2015; Rogerson, 2004a, 2004b, 2008a, 2008b). Currently, the underlying structural features of slum tourism thus allow only "little victories" in terms of the local distribution of benefits in slum destinations.

\section{Qualitative Factors}

Notwithstanding the overall limited evidence for direct economic benefits, slum tourism is often said to have effects of a symbolic, social, and cultural character that may help to improve living conditions in slums. In the investigation of these effects literature has thus far mostly focused on attempting to verify claims made by tour operators about the educational value of their tours. Survey and interview research with tourists pre- and posttour have shown that perceptions about slums and slum dwellers do change as a result of the tour: for example, in Mumbai (Dyson, 2012; Meschkank, 2011), in Cape Town and surrounds (Rolfes et al., 2009), and in Rio de Janeiro (Freire-Medeiros, 2013). Taking a more longitudinal approach, Steinbrink et al. (2015) caution against overstating those effects on long-term attitudes after research with tourists a year after their first tour showed that most of the effects had worn off. Another point of caution relates to the question in what ways attitude changes among visiting tourists may impact the living conditions of slum residents.

Frenzel (2013) argues for theoretical consideration of the role of symbolic effects of slum tourism. Tourism may be understood, accordingly, as a social force that triggers changes in political attitudes regarding how to best address poverty in a given political context. In the context of international visitors to slums, the question is, for example, how the attention of foreign tourists may be translated into political capital for slum residents. Such instances of international solidarity have been observed in a few slum tourism locations (e.g., Johannesburg) (Frenzel, 2014b). However, more often slum tourism's negotiation of poverty and development does avoid direct political language 
and frames the tourist intervention in terms of charity and autonomous provision of urban and international development. Charitable and developmental NGOs increasingly invite tourists to become their agents (as volunteers, see above), their donors, and their marketers in relationships that extend beyond the direct visit with the help of social media. Such touristification of urban social work and international development work is increasingly observable across the globe as case studies from Latin America (Dürr, 2012a, 2012b, discussed above), Africa (Baptista, 2012; Crossley, 2012), Asia (Raes in this issue), and Europe (Burgold, 2014) show. Critically, Crossley (2012) and Baptista (2012) observed how slums and areas of poverty were symbolically rendered into artificial zones of intervention where no actual care was provided. These developments point to the multiple relationships of tourism on the one hand and poverty and inequality on the other. Not only may tourism revenue work to alleviate poverty, rather tourists themselves are increasingly working, both as volunteers and as marketers of the destination, in the quest to tackle poverty, albeit with questionable results.

In urban development tourists' contribution to making slums into attractions also consist of the symbolic attention given to poor urban areas. Tourists cocreate the destination as attention leads to more attention and may increasingly involve local elites. A key example of the power of such developments is the gentrification of favelas in Rio de Janeiro part triggered by tourism (Freire-Medeiros, Vilarouca, \& Menezes, 2013; Steinbrink, 2014). Because of the accumulated attention of ever greater numbers of tourists and other outsiders, the symbolic attention of slum tourists may thus accumulate into increases in real estate prices. Such effects of tourism have been noticed by policy makers. In Medellin the opening of barrios for tourist consumption was supported by public investment in infrastructures and security, piloting the use of cable cars in urban transport, and creating IT infrastructure. Equivalent policies are attempted by authorities in Rio de Janeiro and other cities across Latin America, but as LeBaron (this issue ) observes, the priority for authorities is sometimes not so much social care and benefits, but security. Moreover, as the example of Rio de Janeiro shows, gentrification may lead to displacement of former residents. Slum tourism's symbolic force may thus contribute to the spatial reorganization of poverty, rather than alleviate it.

\section{Resident Perspectives}

Even though the "balanced or harmonious relationship between tourists, the people and places they encounter and the organisations and businesses that provide tourism services" are "fundamental to the successful development of tourism" (Sharpley, 2014, p. 37; see also Zhang, Inbakaran, \& Jackson, 2006), local residents have received little attention in slum tourism scholarship. The theme that has received most attention is the perceived trade-off between the benefits arising from slum tourism and the negative social and environmental consequences of its development. Around the world slum residents recognize the impact of tourism has both been positive and negative. Most detailed work on this matter stems from Rocinha, Brazil. When asked directly, $83 \%$ of residents viewed the development of tourism in their favela as positive. However, from interviews a more ambivalent perspective comes forward as opinions differ among inhabitants and both benefits and disadvantages are recognized (Freire-Medeiros, 2008, 2009, 2012). A similar finding comes from Katutura, Windhoek (Steinbrink et al., 2015). A study in Kibera, Nairobi reveals that residents have a favorable view of tourism, yet still perceive more disadvantages than benefits (Kieti \& Magio, 2013).

When asked about benefits, residents note that slum tourism helps challenge negative stereotypes and breaks the isolation of residents, a sense of pride that foreign tourists are interested in their locality and the overall development of the favela (Chege \& Mwisukha, 2013; Meschkank, 2011; OBrien, 2011; Steinbrink et al. 2015). Few residents mention direct economic gain or employment as benefits, which should come as little surprise, given that only a very small proportion of residents profit directly from slum tourism. In Brazil over three quarters of residents remain unaware of the commercial nature of favela tourism (Freire-Medeiros, 2012). An important disadvantage of slum tourism according to residents is the way their neighborhoods are visited and represented. Some residents are acutely aware of the controversial nature of slum tourism and take offence if they feel misrepresented or uninvolved. In South Africa, for example, drive-by coach tours are long 
maligned (Butler, 1999; Ramchander, 2004), while elsewhere too there is frustration with the commercialization of poverty. Tourism may also lead individuals to feel embarrassed as tourists intrude on residents' privacy, particularly when they take photos without permission (Freire-Medeiros, 2012; Kieti \& Magio, 2013; Søderstrøm, 2014). Such sentiments are a reason for the main tour operator in Dharavi, India to have a strict no-camera policy (Dyson, 2012), but is rarely the case with tour operators in other slums. In addition to this, the limited freedom to interact is often maligned. Slum tourists are commonly accompanied by a tour guide, somewhat sheltered from direct interaction with residents (Duarte, 2010; Meschkank, 2011).

An overarching theme reflecting these disadvantages is the lack of involvement of local residents, not only in the production of slum tourism, but even as part of the slum tourism experience. Indeed, this has been observed in South Africa (Søderstrøm, 2014), India (Dyson, 2012), Brazil (Freire-Medeiros, 2012), Nigeria (Chege \& Mwisukha, 2013; Kennedy, Damiannah, \& Beatrice, 2014), and Windhoek (Steinbrink et al., 2015). Key barriers to interaction include the language barrier, with few residents speaking English, and the mediating role of tour guides who may prevent interaction between residents and tourists due to time limitations or fear of tourists "tipping” the locals at their own expense. In addition, local residents are rarely consulted by tour operators on the future development of slum tourism. This is not necessarily due to a lack of willingness from tour operators, as the majority of residents take little interest in tourism (Freire-Medeiros, 2012). It does mean though that residents remain like mute actors, performing in a play without a say or control on future developments of the direction of slum tourism. Such a lack of control can in the long run lead to feelings of disempowerment among locals and overturn the increase in self-esteem that comes from the interest of foreign tourists in their local community.

Support for slum tourism does appear to be higher when the people responsible for tourist activities share a similar perspective with the rest of the community and local residents participate in the production of slum tourism (Basu, 2012; Duarte, 2010; Kieti \& Magio, 2013). However, one needs to acknowledge that slum communities are complex and their inhabitants commonly have a wide variety of conflicting allegiances and interests (Harvey, 2011). Another aspect that requires attention is the fact that slum residents do not necessarily have a strong sense of place. Kennedy et al. (2014) note that older residents, and those who had lived in Kibera for a longer time, saw slum tourism as less beneficial. However, around Cape Town, local tour operators move out of the townships as soon as they have the opportunity to do so, leaving behind disillusioned residents (Koens, 2014). This highlights ethical questions relating to community involvement in slum tourism-namely who acts, who gains, and who loses (Hall, 2007). Such questions have been insufficiently asked in the context of global slum tourism.

\section{Slum Mobilities}

Arguably, mainstream scholarship in slum tourism is constituted by research investigations that focus on urban slums as destinations for travelers mainly from the global North. In the first decade of slum tourism writings minimal acknowledgement so far has been given to the role of these areas as source regions for tourism. Few studies are pursued of the discretionary mobilities of residents of, for example, Brazil's favelas or South Africa's townships which are core slum tourism destinations. Recently, however, calls have been made for the systematic study of tourists from and within “emerging world regions” (Cohen \& Cohen, 2015). This agenda challenges Eurocentric notions that prioritize Westerners as tourists while representing people from emerging regions simply as hosts or “tourees” (Cohen \& Cohen, 2015; Gladstone, 2005; Winter, 2009). Correspondingly, the neglect of people from emerging regions-including from slum tourism destinations - as tourists is addressed.

A valuable starting point is Cohen and Cohen's (2015) innovative application of the mobilities approach to chart pathways for research about tourism and tourists in the world's emerging regions. Their analysis highlights the utility of Gladstone's (2005) distinctions between a formal and an informal sector of travel and tourism. While acknowledging these "sectors" overlap in practice, it is useful for slum tourism research to focus on the informal economy that is "defined as that part of the travelling public which typically does not make use 
of tourist-oriented means of transportation, accommodations and services" (Cohen \& Cohen, 2015, p. 19). The discretionary mobilities of this informal economy are those of the working classes, the ordinary people and the marginalized rather than of the rising middle classes of the world's emerging tourism regions. Typically, this informal economy of travel and tourism is the largest component of domestic travel and tourism, less regulated and less convenient than its formal sector counterpart (Hannam \& Butler, 2012). In many parts of the global South, however, this informal economy of travel extends beyond domestic tourism with, for example, much regional travel in sub-Saharan Africa assuming these characteristics (Rogerson, 2015). Importantly, it must be understood that key drivers of this informal economy are nonleisure forms of mobilities. Religious pilgrimage and travel for business purposes can be significant components of this informal economy in several areas (Cohen \& Cohen, 2015; Rogerson, 2015). Nevertheless, as a result of historical patterns of rural-urban migration as well as the persistence of circular forms of migration across much of the global South, the activity of visiting friends and relatives (VFR) emerges as the largest component of domestic informal travel as well as an important element of informal regional tourism. The making of translocal households through the splitting and dispersion of family and social networks between urban and rural spaces is the trigger for the occurrence of rhythmic home visits by circulatory migrants, many of whom organize household livelihoods in networks that bridge the urban-rural divide (Dick \& Reuschke, 2012; Lohnert \& Steinbrink, 2005).

Recent research from Southern Africa provides evidence of this informal economy of domestic and regional travel and confirms that the country's townships are as much source areas as destinations for tourists (Rogerson, 2014, in press). As a tourist destination Soweto attracts vastly more domestic than international visitors and in terms of purpose of travel the numbers of leisure visits is far outstripped by visits for non-leisure purposes. Indeed, popular destinations for international slum tourists, such as Soweto or Khayelitsha, are significant source regions for domestic tourists (Rogerson \& Lisa, 2005). The works of Rogerson (2014, in press) and Rogerson and Hoogendoorn (2014) show the growth and expansion of VFR travel between townships and rural areas. This movement is an historical legacy of the creation of South Africa's coercive labor economy anchored on migratory labor movements, the consequent geographical divide of households between urban and rural home spaces, and the continuation of circular migration after democratic transition (Steinbrink, 2009, 2010). Township dwellers become “ordinary” VFR tourists as they negotiate networks of taxis as well as public transportation in order to undertake (often dangerous) trips to rural "second homes" (Hoogendoorn, 2011). In addition, religious pilgrimages are pursued at various periods catalyzing large movements out from township areas to sacred spaces such as Moria (Rogerson, in press). Further mobilities of slum tourists can be for purposes of business; for example, Mozambican residents of townships close to Johannesburg undertake frequent home visits to source local produce (food, music) for trading in South African urban townships. Finally, it must be understood that as certain "slum" destinations of the global South (such as Soweto) become increasingly differentiated in their residential profile, the emergence of a new middle class can result in formal sector leisure travel. Overall, the need exists for a widened horizon of "slum tourism scholarship to include research which examines the tourism mobilities of ordinary residents of townships and favelas” (Rogerson, 2014, p. 31).

\section{In Lieu of a Conclusion, a Call for More Comparative and Conceptual Research}

In this article we have presented an overview of the current state of the art of research on slum tourism. In this last section we want to point to certain gaps that should be addressed in future research projects. This concerns in particular the development of a better theoretical grasp of slum tourism. To date slum tourism research is pursued from a variety of different approaches. As Dürr and Jaffe (2012) have contested, however, there are specific overlaps in the assumptions in which slum tourism has been analyzed. On the one hand, slum tourism research operates on the level of a political economy in which the exchange that takes place is scrutinized for its moral and social value. This avenue of consideration concerns the questions of the benefits 
and costs of slum tourism development, how well resources are shared, and how successful slum tourism is in terms of alleviating poverty. On the other hand, slum tourism research seems to be concerned with questions of representation, pertaining to the authenticity of experiences, the construction of tourist gazes, and the clashes between diverse semantics of the local, the global, the static, and the mobile. Both theoretical contexts often also overlap in the approaches taken by researchers. Arguably they may also converge as representational questions are increasingly important to our understanding of value production and the logic of exchange.

If future slum tourism research is to address these issues, it should opt for comparative and conceptual approaches, which investigate the commonalities of the global slum tourism phenomenon. In this context it is significant to see slum tourism research increasingly being recognized as an important area of study by funding bodies (for an overview of current research projects of slum tourism visit http:// slumtourism.net/research-projects/). Such support is crucial to move beyond case studies. The investigation of those overlaps might provide first insights into the larger theoretical conditions in which slum tourism becomes possible and how findings from slum tourism can help appreciate issues of concern in the wider tourism literature. This helps to not only underline why it matters to study this empirical practice but also, how, if at all, it may contribute to altering the intolerable level of inequality prevalent in today's world.

\section{References}

Allie-Nieftagodien, S. (2013). Pro-poor tourism in Alexandra since 1994: A case study of St Michaels Church and SA Jewel. Unpublished MA Research Report (Tourism), University of the Witwatersrand, Johannesburg.

Aquino, J. F. (2013). Perceived impacts of volunteer tourism in favela communities of Rio de Janeiro, Brazil. Arizona State University. Retrieved from http://gradworks.umi. com/35/90/3590927.html

Baptista, J. A. (2012). Tourism of poverty: The value of being poor in the non-governmental order. In F. Frenzel, K. Koens, \& M. Steinbrink (Eds.), Slum tourism: Poverty, power and ethics (pp. 125-143). London: Routledge.

Basu, K. (2012). Slum tourism: For the poor, by the poor. In F. Frenzel, K. Koens, \& M. Steinbrink (Eds.), Slum tourism: Poverty, power and ethics (pp. 66-82). London: Routledge.
Becklake, S. (2014). NGOs and the creation of development tourism destinations: Exploring the role of development NGOs in the making of 'Destino Guatemala.' Presented at the Destination Slum! 2: New Developments and Perspectives in Slum Tourism Research, Potsdam.

Binder, J. (2004). The whole point of backpacking: Anthropological perspectives on the characteristics of backpacking. In G. Richards \& J. C. Wilson (Eds.), The global nomad: Backpacker travel in theory and practice (pp. 92-108). Clevedon, UK: Channel View.

Booyens, I. (2010). Rethinking township tourism; towards responsible tourism development in South African townships. Development Southern Africa, 27, 273-287.

Burgold J. (2014). Slumming the Global North? Überlegungen zur organisierten Besichtigung gesellschaftlicher Problemlagen in den Metropolen des Globalen Nordens forthcoming in Zeitschrift für Tourismuswissenschaft.

Burgold, J. \& Rolfes, M. (2013). Of voyeuristic safari tours and responsible tourism with educational value: Observing moral communication in slum and township tourism in Cape Town and Mumbai. Die Erde, 144(2), 161-174.

Butcher, J. (2003). The moralisation of tourism: Sun, sandand saving the world? London/New York: Routledge.

Butler, S. R. (1999). Township tours: Packaging the new South Africa. Southern Africa Report Archive, 14, 24-30.

Chege, P., \& Mwisukha, A. (2013). Benefits of slum tourism in Kibera slum in Nairobi, Kenya. International Journal of Arts and Commerce, 2(4), 94-102.

Chege, P. W. \& Waweru, F. K. (2014). Assessment of status, challenges and viability of slum tourism; Case study of Kibera slum in Nairobi, Kenya. Research on Humanities and Social Sciences, 4(6), 38-48.

Cocks, C. (2001). Doing the town. The rise of urban tourism in the United States, 1850-1915. Berkeley, CA: University of California Press.

Cohen, E., \& Cohen, S. A. (2014). A mobilities approach to tourism from emerging world regions. Current Issues in Tourism, 18(1), 11-43.

Conforti, J. (1996). Ghettos as tourism attractions. Annals of Tourism Research, 23(4), 830-842.

Crossley, É. (2012). Poor but happy: Volunteer tourists' encounters with poverty. Tourism Geographies, 14(2), 235-253.

Dick, E., \& Reuschke, D. (2012). Multilocational households in the Global South and North: Relevance, features and spatial Implications. Die Erde, 143(3), 177-194.

Diekmann, A., \& Hannam, K. (2012). Touristic mobilities in India's slum spaces. Annals of Tourism Research, 39(3), 1315-1336.

Dowling, R. M. (2009). Slumming in New York: From the waterfront to mythic Harlem. Champaign, IL: University of Illinois Press.

Duarte, R. (2010). Exploring the social impacts of favela tourism: An insight into the residents'view. M.Sc. thesis, Wageningen University, Wageningen.

Dürr, E. (2012a). Encounters over garbage: Tourists and lifestyle migrants in Mexico. Tourism Geographies, 14(2), 339-355. 
Dürr, E. (2012b). Urban poverty, spatial representation and mobility: Touring a slum in Mexico. International Journal of Urban and Regional Research, 36(4), 706-724. doi:10.1111/j.1468-2427.2012.01123.x

Dürr, E., \& Jaffe, R. (2012). Theorizing slum tourism: Performing, negotiating and transforming inequality. European Review of Latin American \& Caribbean Studies, 93(1), 113-123.

Dyson, P. (2012). Slum tourism: Representing and interpreting “reality” in Dharavi, Mumbai. Tourism Geographies, 14(2), 254-274. doi:10.1080/14616688.2011.609900

Freire-Medeiros, B. (2008). Selling the favela: Thoughts and polemics about a tourist destination. Brazilian Social Sciences Review, 4, 11-26.

Freire-Medeiros, B. (2009). The favela and its touristic transits. Geoforum, 40(4), 580-588.

Freire-Medeiros, B. (2010). Gazing at the poor: Favela tours and the colonial legacy. In London Debates 2010. London: School of Advanced Study, University of London.

Freire-Medeiros, B. (2012). Favela tourism: Listening to local voices. In F. Frenzel, K. Koens, \& M. Steinbrink(Eds.), Slum tourism: Poverty, power and ethics. London: Routledge.

Freire-Medeiros, B. (2013). Touring poverty. London: Routledge.

Freire-Medeiros, B., Vilarouca, M. G. \& Menezes, P. (2013). International tourists in a "pacified" favela: Profiles and attitudes. The case of Santa Marta, Rio de Janeiro. DIE ERDE - Journal of the Geographical Society of Berlin, 144(2), 147-159.

Frenzel, F. (2013). Slum tourism in the context of the tourism and poverty (relief) debate. Die Erde, 144(2), 117-128.

Frenzel, F. (2014a). Slum Tourism and its controversies from a management perspective. In M. Gudic, A. Rosenbloom, \& C. Parkes, eds. Socially Responsive Organizations and the Challenge of Poverty. Leeds, UK: Greenleaf, pp. 23-135.

Frenzel, F. (2014b). Slum Tourism and Urban Regeneration: Touring Inner Johannesburg. Urban Forum, 25(4), 431-447.

Frenzel, F. \& Koens, K. (2012). Slum Tourism: Developments in a young field of interdisciplinary tourism research. Tourism Geographies, 14(2), pp. 1-16.

Frenzel, F., \& Steinbrink, M. (2014). Globaler Armutstourismus. Neue Entwicklungen, Neue Perspektiven. Zeitschrift für Tourismuswissenschaft, 6(2), 219, 222.

Frisch, T. (2012). Glimpses of another world: The favela as a tourist attraction. Tourism Geographies, 14(2), 320-338. doi:10.1080/14616688.2011.609999

Furtado, A. N. S. (2012). O turismo de realidade na Favela Santa Marta: Estudo de caso de uma atividade dita sustentável. Quem Pensa E Faz O Turismo Acontecer, 12, 43-56.

George, R., \& Booyens, I. (2014). Township tourism demand: Tourists' perceptions of safety and security. Urban Forum, 25(4), 449-467.

Gladstone, D. (2005). From pilgrimage to package tour: Travel and tourism in the Third World. Abingdon, UK: Taylor \& Francis.
Hall, C. M. (2007). Pro-poor tourism: Do "tourism exchanges benefit primarily the countries of the south"? Current Issues in Tourism, 10, 2-3.

Hannam, K., \& Butler, G. (2012). Engaging the new mobilities paradigm in contemporary African tourism research. Africa Insight, 42(2), 127-135.

Harvey, R. A. (2011). Tourism is everyone's business: The participants and places of township tourism in Cape Town, South Africa. Ph.D. thesis, University of Florida, Gainesville.

Heap, C. (2009). Slumming: Sexual and racial encounters in American nightlife, 1885-1940. Chicago, IL: Chicago University Press.

Hernandez-Garcia, J. (2013). Slum tourism, city branding and social urbanism: The case of Medellin, Colombia. Journal of Place Management and Development, 6(1), 43-51.

Hoogendoorn, G. (2011). Low-income earners as second home tourists in South Africa. Tourism Review International, 15(1/2), 37-50.

Kennedy, O. M., Damiannah, M. K., \& Beatrice, I. (2014). Residents' perception of slum tourism development in Kibera, Nairobi, Kenya. African Journal of Tourism and Hospitality, 1(1). Retrieved from http://ajth.mu.ac.ke/ index.php/ajth/article/view/4

Kieti, D. M., \& Magio, K. O. (2013). The ethical and local resident perspectives of slum tourism in Kenya. Advances in Hospitality and Tourism Research, 1(1), 35-57.

King, R., \& Dovey, K. (2012). Reading the Bangkok slum. In F. Frenzel, K. Koens, \& M. Steinbrink (Eds.), Slum tourism: Poverty, power and ethics (pp. 159-172). London: Routledge.

Koens, K. (2012). Competition, cooperation and collaboration; Business relations and power in township tourism. In F. Frenzel, K. Koens, \& M. Steinbrink (Eds.), Slum tourism: Poverty, power and ethics. London: Routledge.

Koens, K. (2014). Small businesses and township tourism around Cape Town. Ph.D. thesis, Leeds Metropolitan University, Leeds.

Koens, K., \& Thomas, R. (2015). Is small beautiful? Understanding the contribution of small businesses in township tourism to economic development. Development Southern Africa. doi: 10.1080/0376835X.2015.1010715

Koven, S. (2004). Slumming: Sexual and social politics in Victorian London. Princeton: Princeton University Press.

Linke, U. (2012). Mobile imaginaries, portable signs: The global consumption of iconic representations of slum life. Tourism Geographies, 14(2), 294-319.

Lohnert, B., \& Steinbrink, M. (2005). Rural and urban livelihoods: A translocal perspective in a South African context. South African Geographical Journal, 87(2), 95-105.

MacCannell, D. (1976). The tourist: A new theory of the leisure class. New York: Schocken Books.

McGehee, N. G. (2014). Volunteer tourism: Evolution, issues and futures. Journal of Sustainable Tourism, 22(6), 847-854.

McKay, T. (2013). Leaping into urban adventure: Orlando Bungee, Soweto, South Africa. African Journal for Physical, Health Education, Recreation and Dance, 19(Suppl. 2), 55-71. 
Mekawy, M. A. (2012). Responsible slum tourism: Egyptian experience. Annals of Tourism Research, 39(4), 2092-2113.

Mendes, A. (2010). Showcasing India unshining: Film tourism in Danny Boyle's Slumdog Millionaire. Third Text, 24(4), 471-479.

Menezes, P. (2012). A forgotten place to remember: Reflections on the attempt to turn a favela into a museum. In F. Frenzel, K. Koens, \& M. Steinbrink (Eds.), Slum tourism: Poverty, power and ethics (pp. 103-124). London: Routledge.

Meschkank, J. (2011). Investigations into slum tourism in Mumbai: Poverty tourism and the tensions between different constructions of reality. GeoJournal, 76, 47-62.

Mowforth, I., \& Munt, I. (2009). Tourism and sustainability: A new tourism in the Third World. London: Routledge.

Naidoo, D. (2010). An investigation into the sustainability of township tourism post the 2010 FIFA World Cup-the case of Soweto. M.B.A. thesis, University of Pretoria, Pretoria.

Nemasetoni, I., \& Rogerson, C. M. (2005). Developing small firms in township tourism: Emerging tour operators in Gauteng, South Africa. Urban Forum, 16(2/3), 196-213.

OBrien, P. W. (2011). Business, management and poverty reduction: A role for slum tourism? Journal of Business Diversity, 11(1), 33-46.

Ramchander, P. (2004). Towards the responsible management of the socio-cultural impact of township tourism. Ph.D. thesis, University of Pretoria, Pretoria.

Rogerson, C. M. (2004a). Transforming the South African tourism industry: The emerging black-owned bed and breakfast economy. GeoJournal, 60(3), 273-281.

Rogerson, C. M. (2004b). Urban tourism and small tourism enterprise development in Johannesburg: The case of township tourism. GeoJournal, 60(3), 249-257.

Rogerson, C. M. (2008a). Shared growth and tourism small firm development in South Africa. Tourism Recreation Research, 33(3), 333-338.

Rogerson, C. M. (2008b). Shared growth and urban tourism: Evidence from Soweto, Urban Forum, 19, 395-411.

Rogerson, C. M. (2014). Rethinking slum tourism: Tourism in South Africa's rural slumlands. Bulletin of Geography: Socio-Economic Series, 26, 19-34.

Rogerson, C. M. (2015). Unpacking business tourism mobilities in sub-Saharan Africa. Current Issues in Tourism, 18(1), 44-56.

Rogerson, C. M. (in press). Revisiting VFR tourism in South Africa. South African Geographical Journal, 97.

Rogerson, C. M., \& Hoogendoorn, G. (2014). VFR travel and second homes tourism: The missing link? The case of South Africa. Tourism Review International, 18, 167-178.

Rogerson, C. M., \& Lisa, Z. (2005). 'Sho’t left': Promoting domestic tourism in South Africa. Urban Forum, 16, 88-111.

Rogerson, J. M., \& Slater, D. (2014). Urban volunteer tourism: Orphanages in Johannesburg. Urban Forum, 25(4), 483-499.
Rolfes, M. (2010). Poverty tourism: Theoretical reflections and empirical findings regarding an extraordinary form of tourism. GeoJournal, 75(5), 421-442. doi:10.1007/ s10708-009-9311-8

Rolfes, M., Steinbrink, M., \& Uhl, C. (2009). Townships as attraction: An empirical study of Township Tourism in Cape Town. Potsdam: University of Potsdam.

Ross, E. (2007). Slum travellers. Ladies and London Poverty, 1860-1920. Berkeley/Los Angeles/London: University of California Press.

Sandfort, M. (1987). Tourism in Harlem: Between negative sightseeing and gentrification. Journal of American Culture, 10(2), 99-105.

Seaton, T. (2012). Wanting to live like common people. The literary evolution of slumming. In F. Frenzel, K. Koens, \& M. Steinbrink (Eds.), Slum tourism: Poverty, power and ethics (pp. 21-48). London: Routledge.

Sharpley, R. (2014). Host perceptions of tourism: A review of the research. Tourism Management, 42, 37-49. doi:10. 1016/j.tourman.2013.10.007

Søderstrøm, J. A. (2014). Responsible practice for township tourism. An exploration of stakeholders' opinions, commitments, actions and expectations in the township of Langa, Cape Town. Presented at the Destination Slum! 2: New Developments and Perspectives in Slum Tourism Research, Potsdam.

Steinbrink, M. (2009). Urbanisation, poverty and translocality: Insights from South Africa. African Population Studies, 23(Suppl.), 220-252.

Steinbrink, M. (2010). Football and circular migration systems in South Africa. Africa Spectrum, 45(2), 35-60.

Steinbrink, M. (2012). "We did the slum!”-Urban poverty tourism in historical perspective. Tourism Geographies, 14(2), 1-22. doi:10.1080/14616688.2012.633216

Steinbrink, M. (2014). Festifavelisation: Mega-events, slums and strategic city-staging - the example of Rio de Janeiro. DIE ERDE - Journal of the Geographical Society of Berlin, 144(2), 129-145.

Steinbrink, M., Frenzel, F. \& Koens, K. (2012). Development and globalization of a new trend in tourism. In F. Frenzel, K. Koens, \& M. Steinbrink, eds. Slum Tourism Poverty, Power and Ethics. London: Routledge, 1-18.

Steinbrink, M., Buning, M., Legant, M., Süßenguth, T., \& Schauwinhold, B. (2015). Armut und Tourismus in Windhoek! A case study on township tourism in Windhoek, Namibia. Potsdam: University of Potsdam.

Urry, J. (2002). The tourist gaze (2nd ed.). London: Sage Publications.

Wearing, S. (2001). Volunteer tourism: Experiences that make a difference. Wallingford, UK: CABI.

Weidemann, P. (2014). Hidden Jakarta-Slum tourism, its effects and the reduction of poverty. Presented at the Destination Slum! 2: New Developments and Perspectives in Slum Tourism Research, Potsdam.

Williams, C. (2008). Ghettourism and voyeurism, or challenging stereotypes and raising consciousness? Literary and non-literary forays into the favelas of Rio de Janeiro. Bulletin of Latin American Research, 27(4), 483-500. 
Winter, T. (2009). Asian tourism and the retreat of AngloWestern centrism in tourism theory. Current Issues in Tourism, 12(1), 21-31.

Wiseman, N. (1850). An appeal to the reason and good feeling of the English people on the subject of the Catholic hierarchy. London: Thomas Richardson and Son.
Whyte, K. P., Selinger, E., \& Outterson, K. (2011). Poverty tourism and the problem of consent. Journal of Global Ethics, 7(3), 337-348. doi:10.1080/17449626.2011.635689

Zhang, J., Inbakaran, R. J., \& Jackson, M. S. (2006). Understanding community attitudes towards tourism and hostguest interaction in the urban-rural border region. Tourism Geographies, 8(2), 182-204. 